\title{
Phenotypic and genotypic characterization of antimicrobial susceptibility of avian pathogenic Escherichia coli isolated from broiler chickens
}

\author{
Gamal Younis, Amal Awad and Nada Mohamed \\ Department of Bacteriology, Mycology and Immunology, Faculty of Veterinary Medicine, Mansoura University, \\ El Mansoura, 35516, Egypt. \\ Corresponding author: Amal Awad, e-mail: amalabdo@mans.edu.eg \\ Co-authors: GY: gamalyounis_1@hotmail.com, NM: hazemnada88@yahoo.com \\ Received: 04-05-2017, Accepted: 29-08-2017, Published online: 03-10-2017
}

doi: 10.14202/vetworld.2017.1167-1172 How to cite this article: Younis G, Awad A, Mohamed N (2017) Phenotypic and genotypic characterization of antimicrobial susceptibility of avian pathogenic Escherichia coli isolated from broiler chickens, Veterinary World, 10(10): 1167-1172.

\begin{abstract}
Aim: Avian pathogenic Escherichia coli (APEC) is pathogenic strains of E. coli that are responsible for one of the most common bacterial diseases affecting poultry worldwide. This study was designed to determine the occurrence, antibiotic resistance profile, and antibiotic resistance genes of $E$. coli isolated from diseased and freshly dead broilers.

Materials and Methods: In that context, a total of 200 broilers samples were examined by standard microbiological techniques for isolation of $E$. coli, and tested for their antimicrobial susceptibility against 15 antimicrobial agents using disc diffusion method. In addition, $E$. coli isolates were screened by multiplex polymerase chain reaction for detection of a number of resistance genes including $a a d A 1$ gene encodes streptomycin/neomycin, tet $A$ encodes resistance to tetracycline, sul 1 encodes sulfonamides, and $\beta$-lactamase encoding genes $\left(\mathrm{bla}_{\mathrm{TEM}}\right.$ and $\left.\mathrm{bla}_{\mathrm{SHV}}\right)$.

Results: A total of $73(36.5 \%)$ isolates were biochemically identified as E. coli strains. O78, O2, and O1 are the most prevalent serotypes detected. E. coli displayed a high resistance against penicillin (100\%), followed by cefepime (95.8\%) and a low resistance to norfloxacin $(36.9 \%)$, and chloramphenicol (30\%). Depending on the results of PCR, sul1 gene was the most predominant antibiotic resistant gene (87\%) followed by bla $\mathrm{TEM}_{\mathrm{TEM}}(78 \%)$, tet $A$ genes $(60 \%)$, and aadA (54\%). However, bla $\mathrm{SHV}_{\mathrm{S}}$ had the lowest prevalence $(23 \%)$.

Conclusion: The obtained results demonstrated the importance of studies on APEC and antibiotic resistance genes in our region which associated with intensive poultry industry, aiming to acquire preventive measures to minimize losses due to APEC and associated multidrug-resistance and resistance genes that of high significance to the rational use of antibiotics in clinical and public health.
\end{abstract}

Keywords: antimicrobial resistance, broilers, Escherichia coli, multiplex polymerase chain reaction, resistant genes.

\section{Introduction}

Avian pathogenic Escherichia coli (APEC) is a subgroup of extraintestinal pathogenic E. coli, enters through different routes including genital and respiratory tracts and causes various extraintestinal diseases collectively known as collibacillosis in chickens, which are responsible for high economic losses in the chicken industry [1]. The pathogenicity of APEC allows certain intestinal commensal $E$. coli to become APEC [2]. APEC belongs mostly to the serotypes $\mathrm{O} 1$, $\mathrm{O} 2$, and $\mathrm{O} 78$ or is often nontypable. APEC is also suspected to be a potential zoonotic risk for human [3].

Treatment of diseases caused by E. coli usually necessitates antimicrobial chemotherapy. The decision of using antimicrobial therapy based on the microorganism susceptibility and the drug pharmacokinetics

Copyright: Younis, et al. Open Access. This article is distributed under the terms of the Creative Commons Attribution 4.0 International License (http://creativecommons.org/licenses/by/4.0/), which permits unrestricted use, distribution, and reproduction in any medium, provided you give appropriate credit to the original author(s) and the source, provide a link to the Creative Commons license, and indicate if changes were made. The Creative Commons Public Domain Dedication waiver (http://creativecommons.org/ publicdomain/zero/1.0/) applies to the data made available in this article, unless otherwise stated. for obtaining the required therapeutic concentration at the site of infection and therefore clinical efficacy [4]. Therefore, veterinarians have a restricted choice of antimicrobial agents to use it in the poultry industry, due to problems of multidrug-resistance (MDR) and human health hazard. Moreover, the constant misuse of antimicrobials led to increase rate of antibiotic resistance [5]. Antibiotic resistance is a major problem that threatens human and animal health especially in underdeveloped and developing countries where antibiotics are used without control for prophylaxis and treatment of human and animal illnesses [6]. E. coli present in both human and animals possess resistance to several classes of antibiotics such as aminoglycosides, penicillin, streptomycin, cephalosporins, sulfonamides, tetracycline, and quinolones [7].

Many drug-resistant strains and genes can be transmitted and disseminated between animal and human pathogens, which not only increases the difficulty in treating animal diseases but also threatens the human health [8]. Therefore, the main goal of this study was to, determine the antibiotic resistance profile of APEC isolates and to detect their associated antibiotic resistance genes. 


\section{Materials and Methods}

\section{Ethical approval}

There is no ethical approval necessary.

\section{Samples collection}

In this study, a total of 200 chicken visceral organs (liver, lungs, heart,spleen) and intestinal contents were collected randomly from diseased and freshly dead chicken broilers from different poultry farms located in the district of Mansoura City, Egypt. The chickens were ranged from 35 to 50 days old and showed different forms of diarrhea. The predominant lesions revealed in postmortem examination were ascites, pericarditis, splenitis, perihepatitis, airsacculitis, and peritonitis. Using sterile scissors and tissue forceps, the visceral organs from each bird were collected separately and put in a polyethylene bag and transferred immediately in an ice tank to the laboratory for bacteriological analysis.

\section{Bacteriological examination}

From each chicken visceral organ, $2 \mathrm{~g}$ was directly inoculated in MacConkey broth and incubated for $18 \mathrm{~h}$ at $37^{\circ} \mathrm{C}$. Then, a loopful from the previously inoculated broth was streaked onto MacConkey agar (Oxoid) plates for $24 \mathrm{~h}$ at $37^{\circ} \mathrm{C}$. Rose pink colonies were picked up and streaked onto Eosin Methylene Blue (Oxoid) and incubated overnight at $37^{\circ} \mathrm{C}$. The identification of $E$. coli isolates depends on the colonies morphological characters, and biochemical tests results following Ewing [9]. Further identification of $E$. coli isolates was done using commercial biochemical test kits (bioMerieux API, France).

\section{Serotyping}

Serological identification of $E$. coli isolates was done using rapid diagnostic $E$. coli antisera sets (Denka Seiken Co., Japan) according to Kok et al. [10] at the Department of Food Hygiene Control, University of Benha, Egypt.

\section{Antimicrobial sensitivity testing}

It was performed by disc diffusion method using Muller-Hinton agar using 15 antibiotic disc belongs to seven different antimicrobial classes including sulfamethoxazole (100 $\mu \mathrm{g} / \mathrm{disk})$, levofloxacin $(5 \mu \mathrm{g} / \mathrm{disk})$, chloramphenicol $(30 \mu \mathrm{g} / \mathrm{disk})$, norfloxacine (10 $\mu \mathrm{g} / \mathrm{disk})$, tetracycline $(30 \mu \mathrm{g} / \mathrm{disk})$, streptomycin (10 $\mu \mathrm{g} / \mathrm{disk})$, cefoxitin (30 $\mu \mathrm{g} / \mathrm{disk})$, ampicillin/sulbactam $(10 \mu \mathrm{g} / \mathrm{disk})$, neomycin $(30 \mu \mathrm{g} / \mathrm{disk})$, doxycycline $(30 \mu \mathrm{g} / \mathrm{disk})$, cefepime $(30 \mu \mathrm{g} / \mathrm{disk})$, cefotaxime (30 $\mu \mathrm{g} /$ disk), penicillin (10 $\mu \mathrm{g} /$ disk), amoxicillin $(10 \mu \mathrm{g} /$ disk), and nalidixic acid (30 $\mu \mathrm{g} / \mathrm{disk})$. Interpretation of the results was done following Clinical and Laboratory Standards Institute Guidelines [11].

\section{DNA extraction}

DNA was extracted according to Ramadan et al. [12] briefly; three presumptive E. coli colonies were inoculated into $3 \mathrm{ml}$ trypticase soy broth and incubated for $18 \mathrm{~h}$ at $37^{\circ} \mathrm{C} .1 \mathrm{ml}$ of the previously inoculated broth was centrifuged at 8,000 g for $2 \mathrm{~min}$.
The sediment was washed with DNase/RNase-free water and heated at $95^{\circ} \mathrm{C}$ for $15 \mathrm{~min}$; the supernatants were used as DNA template.

\section{Detecting antimicrobial resistance genes by multi- plex PCR}

Multiplex PCR assay was done targeting five antibiotic resistance genes (bla $\mathrm{TEM}_{\mathrm{TE}}, \mathrm{bla}_{\mathrm{SHV}}, \operatorname{Tet} \mathrm{A}(\mathrm{A})$, Aada2, and sull) of APEC isolates. Primers used for multiplex PCR are as per the previously reported researchers [13-16]. PCR was performed in a total volume of $50 \mu \mathrm{L}$ consisting of $25 \mu \mathrm{L}$ of $2 \mathrm{X}$ PCR Master Mix (Promega, Madison, USA), $1 \mu \mathrm{L}$ of each primer (Metabion, Germany), and $6 \mu \mathrm{L}$ DNA templates. After an initial denaturation at $94^{\circ} \mathrm{C}$ for 5 min, 35 amplification cycles consisting of denaturation at $94^{\circ} \mathrm{C}$ for $30 \mathrm{~s}$, annealing at $54^{\circ} \mathrm{C}$ for 45 $\mathrm{s}$, and extension at $72^{\circ} \mathrm{C}$ for $45 \mathrm{~s}$ per kbp were performed, followed by a final extension at $72^{\circ} \mathrm{C}$ for 10 min. Amplified genes were separated by electrophoresis in a 1.5\% agarose gel. The separated PCR products were visualized under ultraviolet light and photographed.

\section{Results}

Out of 200 examined specimens, E. coli was identified in $36.5 \%(73 / 200)$ of the total examined samples based on morphological and biochemical characteristics. The recovery rate of $E$. coli from different chicken samples was $28.76 \%, 27.39 \%, 23.28 \%$, $15.06 \%$, and $5.46 \%$ form lungs, spleen, heart, liver, and intestinal contents, respectively (Table-1). E. coli isolates were serotyped into 26 serotypes including O1, O2, O78, O26, O153, O114, O91, O121, O44, O63, O158, O171, O146, O124, O15, O8, O145, O117, O166, O128, O111, O55, O119, O159, O6, and O126 (Table-2). O78, O1, and O2 were the most prevalent serotypes with an incidence of $17.8 \%, 9.5 \%$, and $9.5 \%$, respectively.

Phenotypically, the recovered $E$. coli strains were tested for their antimicrobial resistance against 15 antimicrobial agents (Table-3). Resistance was most frequently detected against penicillin (100\%) followed by amoxicillin $(94.5 \%)$, cefepime $(95.8 \%)$, cefoxitin (90.4\%), cefotaxime $(76.7 \%)$, neomycin $(89 \%)$, sulfamethoxazole $(90.4 \%)$, streptomycin $(73.9 \%)$, doxycycline $(69.8 \%)$, tetracycline $(53.4 \%)$, nalidixic acid (49.3\%), ampicillin/sulbactam (46.5\%), levofloxacin (42.4\%), and to lesser extents chloramphenicol (30\%),

Table-1: Number of strains of avian pathogenic $E$. coli isolated from different samples.

\begin{tabular}{lc}
\hline Organs & $\begin{array}{c}\text { Number of isolated strains } \\
\mathbf{n = 7 3}(\mathbf{0})\end{array}$ \\
\hline Lungs & $21(28.76)$ \\
Liver & $11(15.06)$ \\
Spleen & $20(27.39)$ \\
Intestinal contents & $4(5.47)$ \\
Heart & $17(23.28)$ \\
\hline E. coli=Escherichia coli &
\end{tabular}


Table-2: Serogroups of avian pathogenic E. coli.

\begin{tabular}{|c|c|c|c|}
\hline Number of strains $(n=73)$ & Type of samples & Serodiagnosis & Percentages \\
\hline 13 & Lungs (4), spleen (4), heart (3), intestinal content, liver & 078 & 17.8 \\
\hline 7 & Lungs (2), spleen (2), heart, liver, intestinal content & $\mathrm{O} 2: \mathrm{H} 6$ & 9.5 \\
\hline 7 & Lungs (2), heart (3), spleen (2) & $\mathrm{O} 1: \mathrm{H7}$ & 9.5 \\
\hline 4 & Heart (2), lungs, liver & $091: \mathrm{H} 21$ & 5.4 \\
\hline 4 & Spleen, heart, lungs (2) & $\mathrm{O} 8: \mathrm{H} 21$ & 5.4 \\
\hline 3 & Spleen, lungs, liver & $\mathrm{O} 114: \mathrm{H} 4$ & 4 \\
\hline 3 & Lungs (2), heart & $\mathrm{O} 126: \mathrm{H} 21$ & 4 \\
\hline 3 & Heart, spleen, lungs & $\mathrm{O} 26: \mathrm{H} 11$ & 4 \\
\hline 3 & Spleen, liver, lungs & 0145 & 4 \\
\hline 3 & Spleen, liver, heart & O44:H18 & 4 \\
\hline 2 & Intestinal contents, liver & 0166 & 2.7 \\
\hline 2 & Lungs, heart & O117:H7 & 2.7 \\
\hline 2 & Intestinal contents, lungs & O55:H7 & 2.7 \\
\hline 2 & Liver $(2)$ & $\mathrm{O} 111: \mathrm{H} 2$ & 2.7 \\
\hline 2 & Heart, spleen & 0124 & 2.7 \\
\hline 2 & Spleen, heart & O158 & 2.7 \\
\hline 2 & Lungs, heart & O128:H2 & 2.7 \\
\hline 1 & Lungs & O153:H2 & 1.3 \\
\hline 1 & Liver & O119:H6 & 1.3 \\
\hline 1 & Spleen & 063 & 1.3 \\
\hline 1 & Spleen & $\mathrm{O} 15: \mathrm{H} 2$ & 1.3 \\
\hline 1 & Lungs & O159:H21 & 1.3 \\
\hline 1 & Spleen & $\mathrm{O} 171: \mathrm{H} 2$ & 1.3 \\
\hline 1 & Spleen & $\mathrm{O} 146: \mathrm{H} 21$ & 1.3 \\
\hline 1 & Lungs & $\mathrm{O} 6: \mathrm{H} 4$ & 1.3 \\
\hline 1 & Liver & O121:H7 & 1.3 \\
\hline
\end{tabular}

E. coli=Escherichia coli

Table-3: Antibiograms of isolated E. coli strains.

\begin{tabular}{llc}
\hline $\begin{array}{l}\text { Antimicrobial } \\
\text { class }\end{array}$ & $\begin{array}{l}\text { Antimicrobial } \\
\text { agent }\end{array}$ & E. coli $\mathbf{n = 7 3 ( \% )}$ \\
\hline -lactams & Amoxicillin & $69(94.5)$ \\
& Ampicillin/sulbactam & $34(46.5)$ \\
Cephalosporins & Penicillin & $73(100)$ \\
& Cefepime & $70(95.8)$ \\
& Cefoxitin & $66(90.4)$ \\
Sulfonamides & Cefotaxime & $56(76.7)$ \\
Aminoglycosides & Neomycin & $66(90.4)$ \\
Tetracycline & Streptomycin & $65(89)$ \\
& Tetracycline & $54(73.9)$ \\
Phenicols & Doxycycline & $59(53.4)$ \\
Quinolones & Chloramphenicol & $22(30.8)$ \\
& Levofloxacin & $31(42.4)$ \\
& Norfloxacin & $27(36.9)$ \\
& Nalidixic acid & $36(49.3)$ \\
\hline
\end{tabular}

E. coli=Escherichia coli

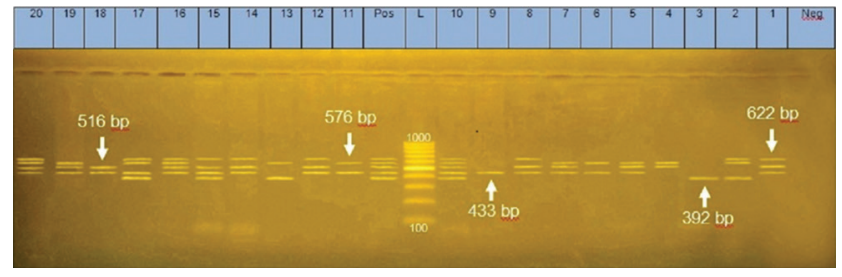

Figure-1: Agarose gel electrophoresis of multiplex PCR showing amplification of five antimicrobial resistance genes, bla $\mathrm{TTM}_{\mathrm{T}}$ at $516 \mathrm{bp}$, sul1 at $433 \mathrm{bp}$ aadAA1 at $622 \mathrm{bp}$, tet $A$ at 576 bp and bla ${ }_{\text {SHV }}$ at 392 bp, Lane L: DNA molecular size marker (1000 bp), Lane Neg: Negative control, Lane Pos: Positive control.

colibacillosis. This disease is a major problem in poultry industry, as it causes high economic losses. Among 200 tested chicken samples, $73(36.5 \%)$ E. coli isolates were recovered. These findings were nearly similar to the findings of Momtaz and Jamshidi [17]. On the other hand, Kiliç et al. [18] recorded a higher recovery rate $(48 \%)$ of $E$. coli out a total of 100 examined chicken samples. In Egypt, 49 (20\%) E. coli strains out of 242 samples were isolated [19], which is relatively lower than our findings.

Serologically, APEC isolates usually belong to certain $\mathrm{O}$ serogroups, especially $\mathrm{O} 1, \mathrm{O} 2, \mathrm{O} 8, \mathrm{O} 15$, O18, O35, O78, O88, O109, and O115 [20]. As first demonstrated by Sojka and Carnaghan [21], O1, $\mathrm{O} 2$, and $\mathrm{O} 78$ are the most frequently isolated from colibacillosis in the many countries worldwide, that proven their role as particularly adapted pathogens that allow involvement in extraintestinal infections [22]. In this study, twenty six $\mathrm{O}$ serogroups were identified among the 73 APEC isolates. Among the isolates that of poultry, but specific strains known as APEC have specific virulence factors and are able to cause avian 
Table-4: Antimicrobial resistance patterns and resistance genes profiles of $E$. coli strains.

\begin{tabular}{|c|c|c|}
\hline $\begin{array}{l}\text { Number of } \\
\text { strains }\end{array}$ & Strain antibiotic phenotypes & Resistance genes identified \\
\hline 3 & FEP, N, SMZ, NOR, NA, AX, P, CTX & bla $_{\mathrm{TEM}}$, aada2, sul1 \\
\hline 4 & FEB, TE, N, S, DO, NA, AX, P, CTX & bla $_{\mathrm{SHV}}, \operatorname{tet} A(\mathrm{~A}), \operatorname{aadA} 2$ \\
\hline 1 & FEP, FOX, S, NA, AX, P, CTX & $b a_{\mathrm{SHV}}$ \\
\hline 2 & FEB, FOX, DO, NA, AX, S, SAM, P, CTX & bla $\mathrm{TTEM}_{\mathrm{TE}}$ tetA $(\mathrm{A})$ \\
\hline 5 & FEP, TE, FOX, S, SMZ, DO, NA, AX, SAM, P, CTX & bla $_{\text {TEM }}, \operatorname{tet} A(\mathrm{~A})$, sul1 \\
\hline 2 & FEB, TE, N, FOX, S, SMZ, DO, AX, P, CTX & $\operatorname{tet} A(A)$, sul 1 \\
\hline 6 & FEB, N, FOX, SMZ, DO, AX, P & bla $_{\mathrm{TEM},}$ tetA $(\mathrm{A})$, sul 1 \\
\hline 5 & FEB, N, FOX, SMZ, C, S, LEV, NOR, AX, SAM, P, CTX & bla $_{\mathrm{TEM}}$, aada2, sul1 \\
\hline 2 & FEB, TE, N, FOX, SMZ, DO, C, NA, AX, P & sul1 \\
\hline 3 & FEP, N, FOX, S, SMZ, LEV, NOR, AX, SAM, P, CTX & bla $_{\mathrm{SHV}}$, bla $\mathrm{TEM}_{\mathrm{TEM}}$ tetA $(\mathrm{A}), \operatorname{aadA} 2$, sul 1 \\
\hline 2 & FEB, TE, N, FOX, S, SMZ, DO, C, LEV, NOR, AX, P, CTX & $\operatorname{TetA}(A)$, sul1 \\
\hline 5 & FEB, N, FOX, S, SMZ, NOR, AX, SAM, P, CTX & bla $_{\mathrm{TEM}}$, aada2, sul 1 \\
\hline 2 & FEB, TE, N, FOX, S, SMZ, DO, LEV, NA, SAM, AX, P, CTX & $b^{\prime} a_{\mathrm{SHV}}$ tetA $(\mathrm{A})$ \\
\hline 4 & FEB, N, FOX, S, SMZ, DO, LEV, NA, AX, P, CTX & bla $_{\mathrm{TEM}}$, aada2, sul 1 \\
\hline 4 & FEP, TE, N, FOX, SMZ, DO, AX, SAM, P, CTX & bla $\mathrm{SHV}^{\prime}$ blaTEM, aada2, sul1 \\
\hline 5 & FEB, TE, N, FOX, SMZ, DO, AX, P, CTX & bla $\mathrm{TEM}^{\prime}$ tetA $(\mathrm{A})$ aada2, sul 1 \\
\hline 3 & TE, N, FOX, S, SMZ, DO, C, NOR, NA, AX, SAM, P, CTX & bla $\mathrm{SHV}_{\mathrm{H}}$ tetA $(\mathrm{A})$, aada2, sul 1 \\
\hline 5 & FEB, N, FOX, S, SMZ, LEV, AX, P & bla $_{\text {TEM, }}$ sul 1 \\
\hline 6 & FEB, TE, N, FOX, S, SMZ, DO, C, LEV, NOR, NA, AX, SAM, P, CTX & bla ${ }_{\text {TEM }}, \operatorname{tet} A(\mathrm{~A})$, sul 1 \\
\hline 4 & FEB, TE, N, FOX, S, SMZ, DO, C, LEV, NA, SAM, P & bla ${ }_{\mathrm{TEM}}, \operatorname{tet} A(\mathrm{~A})$, aada2, sul 1 \\
\hline
\end{tabular}

E. coli=Escherichia coli

could be typed, the most prevalent serogroups were O78, $\mathrm{O} 2$ and $\mathrm{O} 1$ with a prevalence of $17.8 \%, 9.5 \%$, and $9.5 \%$, respectively. In many studies conducted in Egypt, nearly the same serotypes with a predominance of O78 have been identified [12,23,24].

Antimicrobial agents are used in the prevention and treatment of infections and can also use as growth promoting agents in animals. Under the pressure of antibiotic selection, MDR bacteria have been aroused. In this study, E. coli showed a high rate of resistance to most antimicrobials tested. $100 \%$ of the tested $E$. coli isolates showed resistance against penicillin, $95.8 \%$ to cefepime and $94.5 \%$ to amoxicillin followed by considerable resistance to the rest of the examined agents. Most of these antimicrobials are regularly used as growth promoters or as prophylactic agents in the poultry industry in Egypt $[25,26]$ and concurred with the previous reports [27-32].

Many studies have been reported the presence of antibiotic resistance genes in APEC strains [33]. The resistance genes mediated by plasmid can make the resistance prevail among various bacteria that lead to acquiring resistance genes without difficulty and produce MDR [34,35].

Phenotypic multi-resistance of $E$. coli isolates to aminoglycoside, $\beta$-lactams, tetracycline, and sulfonamides antibiotics could be attributed to the presence of aadA, bla ${ }_{\mathrm{TEM}}, \operatorname{tet} A(A)$, and sull resistance genes, respectively, among the tested isolates. Regarding the distribution of these antibiotic resistance genes among $E$. coli isolates, sull was detected in $64(87 \%)$ isolates and bla ${ }_{\mathrm{TEM}}$ identified in $57(78 \%)$ isolates meanwhile tet $A$ gene was identified in $44(60 \%)$ isolates, $40(54 \%)$ isolates were harbored aadA, and 17 (23.28\%) isolates were carried bla $_{\mathrm{SHV}}$. These findings agree with Ammar et al. [19] who found that bla ${ }_{\text {TEM }}$ and sull genes had the highest prevalence among the tested antibiotic resist genes which have being amplified in all tested isolates $(100 \%)$. In addition, bla ${ }_{\mathrm{TEM}}$ was detected in most of $\beta$-lactams resistance strains, similar results were reported by Ali [36]. In contrast to our results, a relatively higher prevalence of bla $\mathrm{SHV}_{\mathrm{S}}$ was previously recorded in Spain (88\%) [13] and Egypt (79\%) [37]. These results are signifying that the results of antibiotic disc diffusion test actually agreed with the results of PCR for detection of the relevant antibiotic resistance genes.

The risk of spreading antibiotic resistance genes to humans should be considered when there is contamination of animal products, especially chickens, by bacterial strains resistant to most of antibiotics [38]. Recently, many of extended-spectrum beta-lactamases (ESBL) producing E. coli have become a worldwide issue. The ESBL-positive $E$. coli strains are highly resistant to a wide range of antibiotics. Controlling such strains with usually used antibiotics is ineffective; recently, there are few antibacterial alternatives that remain effective against these MDR pathogens [39].

\section{Conclusion}

It is very important to control APEC because it represents a grave danger to poultry and is a potential source of transferring MDR genes to human-specific E. coli or other bacteria such as Staphylococcus aureus and Shigella strains. The fact that this pathogen is naturally present in daily consumed food should be considered as a serious public health and food biosafety.

\section{Authors' Contributions}

GY design the study shared in data analysis and revised the manuscript. AA and NM shared in samples collection, performing the tests, manuscript writing 
and data analysis. All authors read and approved the final manuscript.

\section{Acknowledgments}

The authors like to thank the Department of Bacteriology, Mycology and Immunology, Faculty of Veterinary Medicine, Mansoura University, for providing instruments and devices. The authors declared that they did not have any funding source to support their study.

\section{Competing Interests}

The authors declare that they have no competing interests.

\section{References}

1. Matthijs, M.G., Ariaans, M.P., Dwars, R.M., van Eck, J.H., Bouma, A., Stegeman, A. and Vervelde, L. (2009) Course of infection and immune responses in the respiratory tract of IBV infected broilers after superinfection with E. coli. Vet. Immunol. Immunopathol., 127(1): 77-84.

2. Schouler, C., Schaeffer, B., Brée, A., Mora, A., Dahbi, G., Biet, F., Oswald, E., Mainil, J., Blanco, J. and MoulinSchouleur, M. (2012) Diagnostic strategy for identifying avian pathogenic Escherichia coli based on four patterns of virulence genes. J. Clin. Microbiol., 50(5): 1673-1678.

3. Mellata, M. (2013) Human and avian extraintestinal pathogenic Escherichia coli: Infections, zoonotic risks, and antibiotic resistance trends. Foodborne Pathog Dis., 10: 916-932

4. McKellar, Q.A., Sanchez-Bruni, S.F. and Jones, D.G. (2004) Pharmacokinetic/pharmacodynamic relationships of antimicrobial drugs used in veterinary medicine. $J$. Vet. Pharmacol. Ther., 27(6): 503-514.

5. Spellberg, B. (2014) The future of antibiotics. Crit. Care, 18(3): 228.

6. Spellberg, B. and Gilbert, D.N. (2014) The future of antibiotics and resistance: A tribute to a career of leadership by John Bartlett. Clin. Infect. Dis., 59 Suppl 2: S71-S75.

7. Ma, J., Liu, J.H., Luchao, L., Zong, Z., Sun, Y., Zheng, H., Chen, Z. and Zeng, Z.L. (2012) Characterization of extended-spectrum $\beta$-lactamase genes found among Escherichia coli isolates from duck and environmental samples obtained on a duck farm. Appl. Environ. Microbial., 76(10): 3668-3673.

8. Collignon, P., Wegener, H.C., Braam, P. and Butler, C.D. (2005) The routine use of antibiotics to promote animal growth does little to benefit protein undernutrition in the developing world. Clin. Infect. Dis., 41: 1007-1013.

9. Ewing, W.H. (1986) Identification of Enterobacteriaceae by biochemical reactions. In: Edwards and Ewing's Identification of Enterobacteriaceae. Elsevier Science Publishing Co. Inc., New York. NY. p47-72.

10. Kok, T., Worswich, D. and Gowans, E. (1996) Some serological techniques for microbial and viral infections. In: Collee, J., Fraser, A., Marmion, B. and Simmons, A., editors. Practical Medical Microbiology. 14th ed. Churchill Livingstone, Edinburgh, UK.

11. CLSI. (2011) Performance Standards for Antimicrobial Susceptibility Testing, Twenty-First Informational Supplement. Vol. 31. Clinical and Laboratory Standards Institute M02-A10 and M07-A08, Wayne, PA.

12. Ramadan, H., Awad, A. and Ateya, A. (2016) Detection of phenotypes, virulence genes and phylotypes of avian pathogenic and human diarrheagenic Escherichia coli in Egypt. J. Infect. Dev. Ctries., 10(6): 584-591.

13. Colom, K., Perez, J., Alonso, R., Fernandez-Aranguiz, A., Larino, E. and Cisterna, R. (2003) Simple and reliable multiplex PCR assay for detection of blaTEM, blaSHV and
blaOXA-1 genes in Enterobacteriaceae. FEMS Microbial., 2: 147-51.

14. Randall, L.P., Cooles, S.W., Osborn, M.K., Piddock, L.J.V. and Woodward, M.J. (2004) Antibiotic resistance genes, integrons and multiple antibiotic resistance in thirty-five serotypes of Salmonella enterica isolated from humans and animals in the UK. J. Antimicrob. Chemother, 53: 208-216.

15. Bekwe, A.M., Murinda, S.E. and Graves, A.K. (2011) Genetic diversity and antimicrobial resistance of Escherichia coli from human and animal sources uncovers multiple resistances from human sources. PLoS One, 6(6): e20819.

16. Walker, R.A., Lindsay, E., Woodward, M.J., Ward, L.R. and Threlfall, E.J. (2001) Variation in clonality and antibiotic-resistance genes among multi-resistant Salmonella enterica serotype Typhimurium phage-type U302 (MR U302) from humans, animals, and foods. Microbiol. Res., 7: 13-21.

17. Momtaz, H. and Jamshidi, A. (2013) Shiga toxin-producing Escherichia coli isolated from chicken meat in Iran: Serogroups, virulence factors, and antimicrobial resistance properties. Poult. Sci., 92(5): 1305-1313.

18. Kiliç, A., Ertaş, H.B., Muz, A., Özbey, G. and Kalender, H. (2007) Detection of the eaeA gene in Escherichia coli from chickens by polymerase chain reaction. Turk. J. Vet. Anim. Sci., 31(4): 215-218.

19. Ammar, A.M., El-Hamid, M.I., Eid, S.E.A. and El Oksh, A.S. (2015) Insight into antimicrobial resistance and virulence genes of emergent multidrug resistant avian pathogenic Escherichia coli in Egypt: How closely related are they? Rev. Med. Vet., 166(9-10): 304-314.

20. Gross, W.G. (1994) Diseases due to Escherichia coli in poultry. In: Gylcs, C.L., editor. Domestic Animals and Man. CAB International, Wallingford, UK. p237-259.

21. Sojka, W.J. and Carnaghan, R.B.A. (1961) Escherichia coli infection in poultry. Res. Vet. Sci., 2: 340-352.

22. Ewers, C., Janben, T., Kiebling, S., Philipp, H.C. and Wieler, L.H. (2004) Molecular epidemiology of avian pathogenic Escherichia coli (APEC) isolated from colisepticemia in poultry. Vet. Microb., 104(1): 91-101.

23. El-Seedy, F.R., Hassan, W.H., Salama, S.S. and Gamal, F. (2011) Optimization of polymerase chain reaction for direct detection of colibacillosis in infected chickens. Vet. Med. J. Giza, 59(2): 307-318.

24. Reda, M.L. (2013) Studies on antibiotic resistance of Escherichia coli isolated from poultry and children. Suez Canal Vet. Med. J., 18(2), 27-40.

25. Szmolka, A. and Nagy, B. (2013) Multidrug resistant commensal Escherichia coli in animals and its impact for public health. Front. Microbiol., 4: 258-270.

26. Awad, A., Arafat, N. and Elhadidy, M. (2016) Genetic elements associated with antimicrobial resistance among avian pathogenic E. Coli. Ann. Clin. Microbiol. Antimicrob., 15(1): 59.

27. Yang, H., Chen, S., White, D.G., Zhao, S., McDermott, P., Walker, R. and Meng, J. (2004) Characterization of multiple-antimicrobial-resistant Escherichia coli isolates from diseased chickens and swine in China. J. Clin. Microbiol., 42(8): 3483-3489.

28. Johnson, T.J., Siek, K.E., Johnson, S.J. and Nolan, L.K. (2005) DNA sequence and comparative genomics of pAPEC-O2-R, an avian pathogenic Escherichia coli transmissible R plasmid. Antimicrob. Agents Chemother., 49(11): 4681-4688.

29. Kim, T.E., Jeong, Y.W., Cho, S.H., Kim, S.J. and Kwon, H.J. (2007) Chronological study of antibiotic resistances and their relevant genes in Korean avian pathogenic Escherichia coli isolates. J. Clin. Microbial., 45(10): 3309-3315.

30. Randall, L.P., Clouting, C., Horton, R.A., Coldham, N.G., Wu, G., Clifton-Hadley, F.A. and Teale, C.J. (2010) Prevalence of Escherichia coli carrying 
extended-spectrum $\beta$-lactamases (CTX-M and TEM-52) from broiler chickens and turkeys in Great Britain between 2006 and 2009. J. Antimicrob. Chemother, 66(1): 86-95.

31. Obeng, A.S., Rickard, H., Ndi, O., Sexton, M. and Barton, M. (2012) Antibiotic resistance, phylogenetic grouping and virulence potential of Escherichia coli isolated from the faeces of intensively farmed and free range poultry. Vet. Microbiol., 154(3): 305-315.

32. Mohamed, M.A., Shehata, M.A. and Rafeek, E. (2014) Virulence genes content and antimicrobial resistance in Escherichia coli from broiler chickens. Hindawi Publ. Corp. Vet. Med. Int., 2014: Article ID: 195189, 6.

33. Ahmed, A.M. and Shimamoto, T. (2013) Molecular characterization of multidrug-resistant avian pathogenic Escherichia coli isolated from septicemic broilers. Int. J. Med. Microbiol., 303: 475-483.

34. Mosquito, S., Ruiz, J., Pons, M.J., Durand, D., Barletta, F. and Ochoa, T.J. (2012) Molecular mechanisms of antibiotic resistance in diarrhoeagenic Escherichia coli isolated from children. Int. J. Antimicrob. Agents, 40: 544-548.
35. Liu, X.Q., Boothe, D.M., Thungrat, K. and Aly, S. (2012) Mechanisms accounting for fluoroquinolone multidrug resistance Escherichia coli isolated from companion animals. Vet. Microbiol., 161(1-2): 159-168.

36. Ali, M.S. (2009) Studies on Enteropathogenic Escherichia coli from Different Sources, M.V.SC. Thesis (Bacteriology, Mycology and Immunology), Faculty of Veterinary Medicine, Zagazig University.

37. Eid, S.E.A. and Erfan, A.M. (2013) Characterization of $E$. coli associated with high mortality of poultry flocks. Assiut Vet. Med. J., 59: 51-61.

38. Manges, A.R., Smith, S.P., Lau, B.J., Nuval, C.J., Eisenberg, J.N., Dietrich, P.S. and Riley, L.W. (2007) Retail meat consumption and the acquisition of antimicrobial resistant Escherichia coli causing urinary tract infections: A case-control study. Foodborne Pathog. Dis., 4(4): 419-431.

39. Paterson, D.L. and Bonomo, R.A. (2005) Extendedspectrum beta-lactamases: A clinical update. Clin. Microbiol. Rev., 18(4): 657-686.

\section{$* * * * * * * *$}

